УДК 3.982.22:553.981.2:551.87

DOI: http://doi.org/10.17721/1728-2713.94.09

V. Gurbanov,
E-mail :vaqifqurbanov@mail.ru;

N. Narimanov,

E-mail: nariman.narimanov40@asoiu.edu.az;

G. Nasibova

E-mail: gultar_nasibova_1@yahoo.com

Azerbaijan State Oil and Industry University,

34, Azadlig Ave., Baku, AZ1010, Azerbaijan

\title{
IMPACT OF COMPRESSIONAL STRESSES WITHIN THE SOUTH CASPIAN MEGADEPRESSION UPON EVOLUTION AND OIL AND GAS CONTENT OF LOCAL UPLIFTS
}

(Представлено членом редакційної колегії д-ром геол. наук, проф. О.М. Карпенком)

The following structural elements in the South Caspian megadepression (SCMD) have been considered: the interfluve of the Kura and Gabirri, the Absheron and Baku archipelagoes, the Lower Kur depression (LKD) and the Godin massif, that stand out geodynamically, from point of view of structural and tectonic evolution and oil and gas content.

To solve this problem, the geodynamic environment of the SCMD has been analyzed based on the geodynamic chart of the Central segment of the Mediterranean folding belt compiled by the author, as well as the orientation chart of compressional stresses in the SCD and the methodology, developed for the first time ever, for their qualitative assessment within the structural elements by means of compiling isomorphic maps. The latter make it possible to determine the intensity and nature of the propagation of compressional stresses, the specifics of their impact on folding, oil and gas generation and formation of hydrocarbon accumulations.

The Kur-Gabirri interfluve is situated in the west of the SCMD between the closely located Greater and Lesser Caucasian collisions. It is characterized by oil and gas bearing and potential sublatitudinally oriented linear folds, complicated by faulting and mud volcanism. The values of isolines of the isomorphic map and their density are indicative of high intensity of the north-west oriented compressional stresses here.

The Absheron archipelago is a western element of the Absheron-Balkhan residual subduction. According to the isomorphic map with a dense network of isolines of sublatitudinal orientation, the archipelago is complicated by linear folding, as well as thrusts, transverse strike-slip faults, mud volcanism, oil and gas content, and oil and gas manifestations indicating the build-up of intense compressional stresses here.

Evolution of folds within the Baku archipelago and the Lower Kur depression took place under the stresses of longitudinal and transverse bending.

The faintly pronounced linearity of the compressional stresses is apparently associated with the formation of the Western Board of the SCD in the form of a regional submeridianal uplift. It developed under the impact of compressional stresses arising from the effect of the northeastern projection of the Arabian plate on the Iranian one. LKD is an onshore extension of the Baku archipelago. Its anticline zones, regional faults, mud volcanism and oil and gas content continue in the latter.

The Godin Massif is the easternmost structural element of those considered with a faintly pronounced reflected folding of unknown prospects. Isolines of the isomorphic map are not directly associated with local uplifts, which is indicative of the absence of clearly pronounced compressional stresses here.

The analysis made it possible to determine the degree of development of compressional stresses, their impact upon formation of the sedimentary section, folding, mud volcanism and oil and gas content of the considered structural elements.

Keywords: mud volcanism, compressive stresses, isomorph, Absheron archipelago, oil, gas.

Introduction. The geodynamic environment of formation of the South Caspian Megadepression (SCMD) (Fig. 1) and the map of lithospheric plates around it shows that the South Caspian basin had been one of the deep depressions of the Tethys ocean until the end of the
Miocene, located between the Iranian plate and Eurasia. The South Caspian marginal continental basin was formed as a result of convergence of the Iranian and Anatolian plates with Eurasia at the end of the Eocene (Gamkrelidze, 1982).

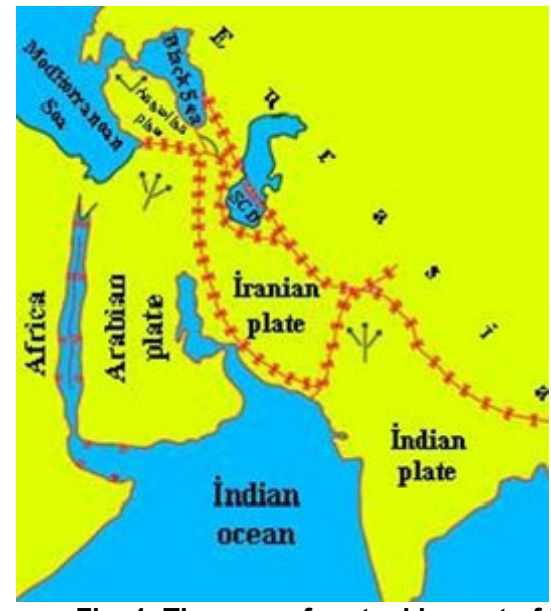

Fig. 1. The map of mutual impact of lithospheric plates in the central segment of Mediterranean Sea Belt (after N.R. Narimanov)
The Greater and the Lesser Caucasus collisions had been subjected to intensive uplift and convergence during the Later Miocene. It was caused by formation of two subduction zones: one of them oriented northwards beneath 
the Greater Caucasus, the second one - southwards, under the Lesser Caucasus (Zonenshayn et al., 1990;
Ahmedov, 1987). Such a geodynamic environment caused the SCMD to undergo intense compressional stresses.

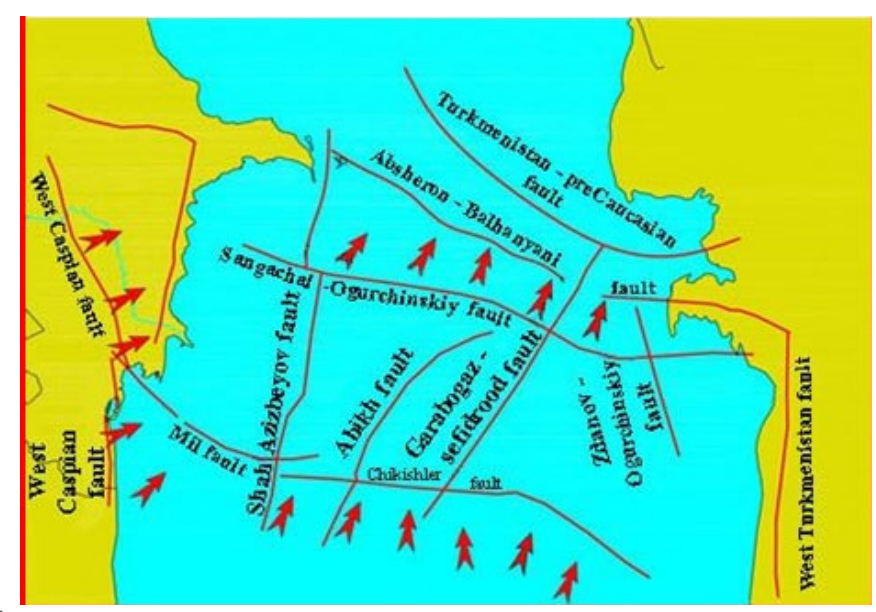

$\Longrightarrow$ - Impact direction of compressional stresses

Faults

Fig. 2. Impact direction of compressional stresses in the South Caspian depression

Since the SCD is subject to compressional stresses from the south, west and north (Fig. 2), each of its structural units is under compressional stresses of varying extent, thus, local uplifts of various size and shape are formed within them as a function of the thickness of the sedimentary mantle, its lithological content, depth of the basement and other factors. Qualitative estimation of intensity and direction of impact of those stresses can be established through investigation of morphological properties and attitude of local uplifts developed within each of the SCD structural units.

Purpose. Based on the ratio of dimensions of local uplifts located within the Kur-Gabirri depression, Absheron and Baku archipelagoes, Kur depression and Turkmen shelf we attempted to qualitatively estimate and study the orientation of compressional stresses and their impact upon a series of geological processes. Isomorphic maps of the abovementioned structural units and diagrams that reflect the morphology of local uplifts have been analyzed for this purpose.

Methods. It is known that folds complicated by mud volcanoes are attributed to injection structures and they are formed within circum-Pacific mobile and Alpine-Himalayan orogenic belts where compressional stresses are widespread. As a result, during formation of diapiric folds they may be of isometric (in the absence of impact of compressional stresses upon evolution of mud diapirs), short brachiform (during weak impact of compressional stresses upon the process of a diapir formation) and either long brachiform or linear shape (during active effect of compressional stresses upon formation of injection structures) as a function of the extent of compressional stresses. Apparently, morphology of a fold, in that case, depends on intensity of impact of compressional stresses upon the diapiric fold formation process. The developed technique for qualitative assessment of the intensity of compressional stresses is based on their significance in evolution of mud diapirs with fold morphology taken into consideration.

Solution. Since the Kur-Gabirri depression had formed in the area where the Greater and Lesser Caucasus collisions are in closest proximity to each other, compressional stresses generated there have greater significance for folding. The isomorphic map (Fig. 3) built for the structural unit under investigation shows general orientation of isolines in west-northwest - east-south-east direction, their higher density widthwise the depression and higher values $(7,0-3,4)$, that reflect higher levels of compressional stresses in the area. The morphological chart points at absolute prevalence of long brachifolds along with their ordered arrangement in west-north-west - east-south-east direction (Fig. 3)

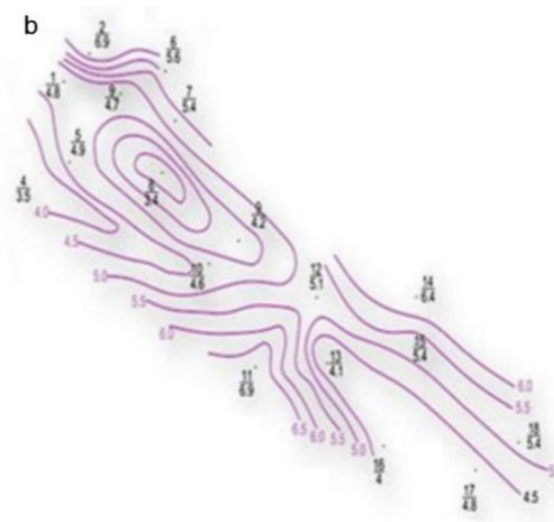

- stretched brachyfolds -shortened brachyfolds

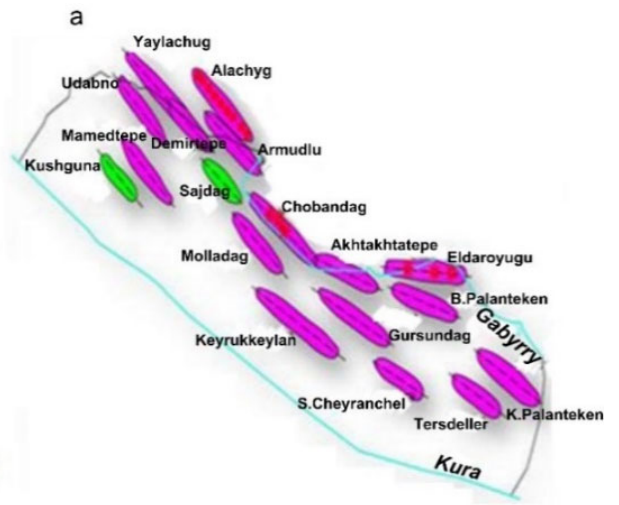

mud volcano numbers and dimensions ratios of local folds

Fig. 3. Scaled morphological depiction of local uplifts of the Kura-Gabyrry depression (a) and its isomorphic map (b) 
Linear arrangement of numerous salsas, gryphons, mud mounds within the Kur-Gabirri depression in general Caucasian direction and their genetic linkage to overthrust faults, in particular, indicate the major role of compressional stresses in formation of these uplifts (Rahmanov, 1995). Extensive development of mud volcanoes of various forms and dislocations of various types, as a result of activity of compressional stresses, could, on the other hand, be estimated as a factor with a negative impact upon the oil and gas content of the Kur-Gabirri depression. However, zones of the footwall reservoir rocks (screened by hanging walls) of the large amplitude overthrusts that complicate the structural and tectonic design of the area may have preserved their oil and gas prospects. Just 2 out of 17 local uplifts of the Kur-Gabirri interfluvial depression have been complicated by mud volcanoes (Fig. 3). In spite of that over 100 salsas, gryphons and mud mounds have developed in the area (Rahmanov, 1995). Low number of mud volcanoes within the territory is related to a relatively small thickness (11-13 km) of the sedimentary mantle and its shale content which is not so high. It is apparent from the isomorphic map of the depression (Fig. 3) that the intensity of developed compressional stresses is high enough and isoline values vary between $3,4-6,9$. This case demonstrates the general level of compressional stress background. The table of established oil and gas content for local uplifts of the structural units of the South Caspian depression gives us 3 oil-bearing local uplifts out of 17 under investigation in the depression with the rest deemed perspective (Aliyev et al., 1984).

From geodynamic point of view, the Absheron Ridge that makes up north-north-eastern slope of the SCD is a structural-tectonic manifestation of a non-classical subduction zone. Compressional stresses that have an impact upon the Absheron Ridge in longitudinal direction are significantly more intense than those within the SCB and despite being extension of compressional stresses of corresponding collision zones they are significantly less intense. This is caused by Kopetdag collision that takes place to the east from the Absheron relict subduction and prevents normal processes and turning it into collision. Nonetheless, the structural-tectonic layout of the zone, complication of the structural megasaddle (Absheron Ridge) by overthrusts, even by nappes and latitudinal strike-slip faults, arrangement of local uplifts in sublatitudinal direction give grounds for the statement of rather intensecompressional stresses of submeridional trend (Narimanov, 2005) (Fig. 4).

Established oil and gas content for local uplifts of the structural units of the South Caspian depression

Table

\begin{tabular}{|c|c|c|c|c|c|c|}
\hline & \multirow{2}{*}{ Number of folds } & \multicolumn{5}{|c|}{ Oil and gas content } \\
\hline & & Oil bearing & Gas bearing & Oil and gas bearing & Perspective & Mud volcanoes \\
\hline \multirow{2}{*}{1} & & \multicolumn{5}{|c|}{ Kur-Gabyrry depression } \\
\hline & 17 & 3 & - & - & 14 & 2 \\
\hline \multirow{2}{*}{ II } & & \multicolumn{5}{|c|}{ Absheron oil and gas bearing province } \\
\hline & 51 & 21 & 4 & 7 & 19 & 53 \\
\hline \multirow[b]{2}{*}{ III } & & \multicolumn{5}{|c|}{ Baku Archipelago oil and gas bearing province } \\
\hline & 21 & 3 & 1 & 3 & 14 & 13 \\
\hline \multirow[b]{2}{*}{ IV } & & \multicolumn{5}{|c|}{ Lower Kur oil and gas bearing province } \\
\hline & 17 & 10 & 2 & 2 & 3 & 10 \\
\hline \multirow{2}{*}{ V } & & \multicolumn{5}{|c|}{ Godinmassif } \\
\hline & 14 & - & - & - & - & 1 \\
\hline
\end{tabular}

Comparison of the isomorphic maps of the areas under investigation shows that the isoline values of the Absheron isomorphic map variate within a higher range $(2,1-9,0)$ and they are denser. Formation of mud volcanoes, that are widespread in the Absheron archipelago, mainly in the structures that are located along the Absheron Ridge axis is indicative of the archipelago as a zone subject to relatively more intense stresses. There are 53 mud volcanoes on 51 structures of the Absheron archipelago, i.e. some folds have been complicated by two mud volcanoes. Variation of isoline values in the range of 2,1-9,0 shows that compressional stresses are more intense than within the Baku archipelago. As mentioned above, this is caused by the Absheron Ridge being, from geodynamic point of view, a relict subduction zone. Out of 51 folds within the archipelago 21 are oil-, 4 - gas-, 7 - oil and gas bearing, the remaining folds are considered perspective. It is obvious that 32 local uplifts of this structural unit are oil and gas bearing, the remaining 19 are prospective (Aliyev et al., 1984).

Compressional stresses of the following structural unit, which is being studied, that is, the Baku Archipelago (Aliyev et al., 1984), not only caused evolution of the local uplifts, but also a submeridionally extended regional uplift that constitutes the western slope of the South Caspian basin between the Lower Kur and the Baku Archipelago (Narimanov, 2005). Compressional stresses of the Baku Archipelago are of the east-north-east trend. Active longitudinal and lateral bending mechanisms exert influence upon formation of local uplifts as brachifolds and on the density of isomorphic lines. On the other hand, it should be noted that evolution of mud volcanism in any area is manifestation of presence of compressional stresses therein, since mud volcanoes are widespread within western mobile zone of the Pacific basin and the Alpine-Himalayan orogenic belt, wherein compressional stresses are widely distributed (Rahmanov, 1995). The structural units under investigation are located within the central segment of the Alpine-Himalayan orogenic belt, along with being constituent parts of the SCMD. In most cases areas complicated by mud volcanism are characterized, as a rule, by higher oil and gas potential.

One can come to the conclusion that compressional stress, mud volcanism and hydrocarbon content present in negative geostructural elements of regions with active geodynamic and tectonic drives are all parts of a single process. From this perspective it should be noted that 13 out of 21 local uplifts under investigation have been complicated by mud volcanoes, 3 of them are oil, 1 - gas, 3 - oil and gas bearing, the remaining ones are considered as potential structures from perspective of hydrocarbon content. Isoline values on the isomorphic map representing intensity of compressional stresses within the Baku Archipelago range between 2,5-6,1 (Fig. 5).

Since the Lower Kur depression is wider than the KurGabirri depression and is more distant from Greater and Lesser Caucasus and Talish collision zones, the impact of compressional stresses formed in them is weaker than that 
exerted upon the Kur-Gabirri depression. The isomorphic map built for this area reflects denser isolines and mainly long brachifolds formed in the north with relatively sparse isomorphic lines and short brachiform local uplifts, what is indicative of relatively more intense compressional stresses in the northern part of the Lower Kur depression than in the southern one (Fig. 6).

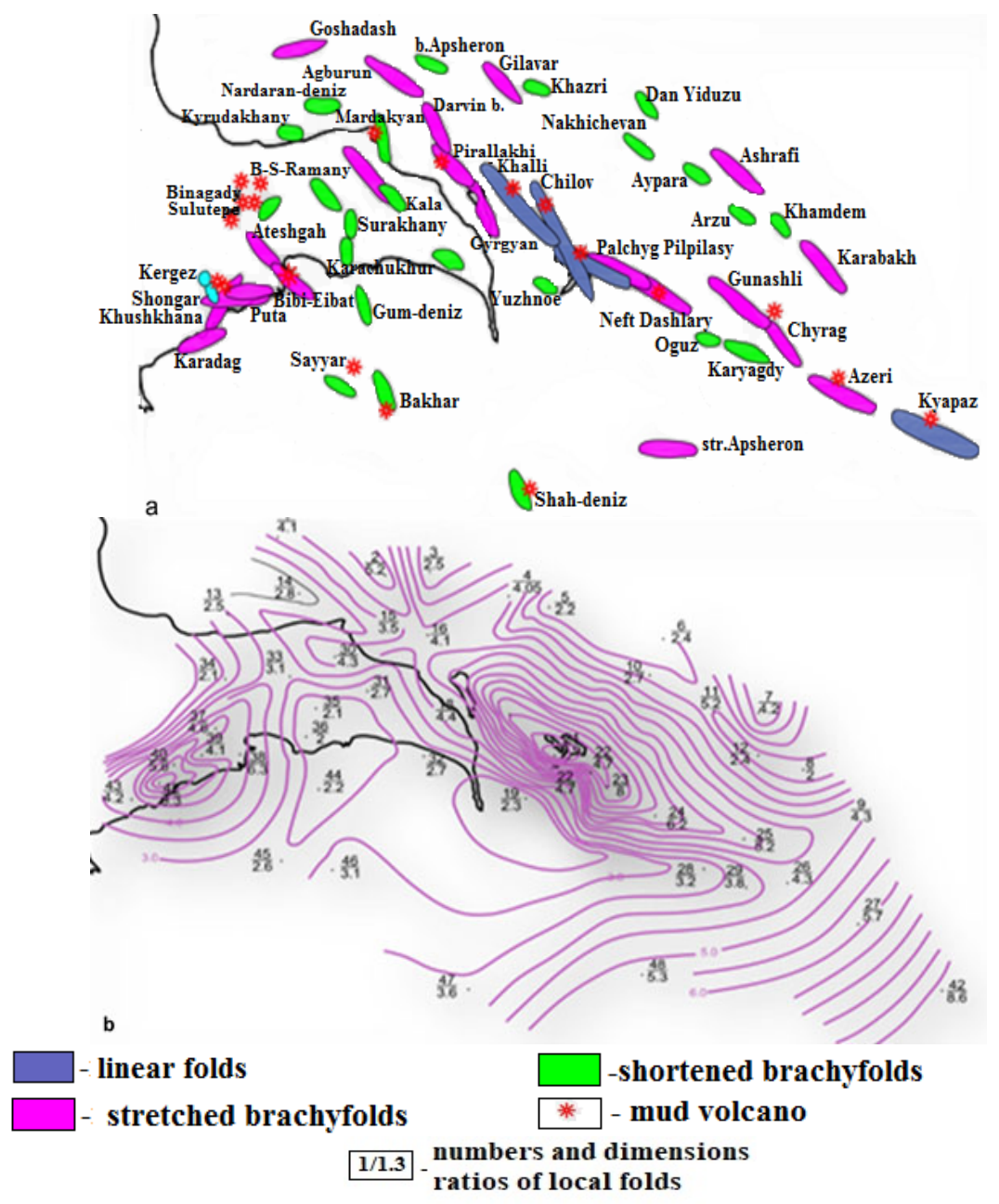

Fig. 4. Scaled morphological depiction of local uplifts of the Absheron archipelago (a) and its isomorphic map (b)

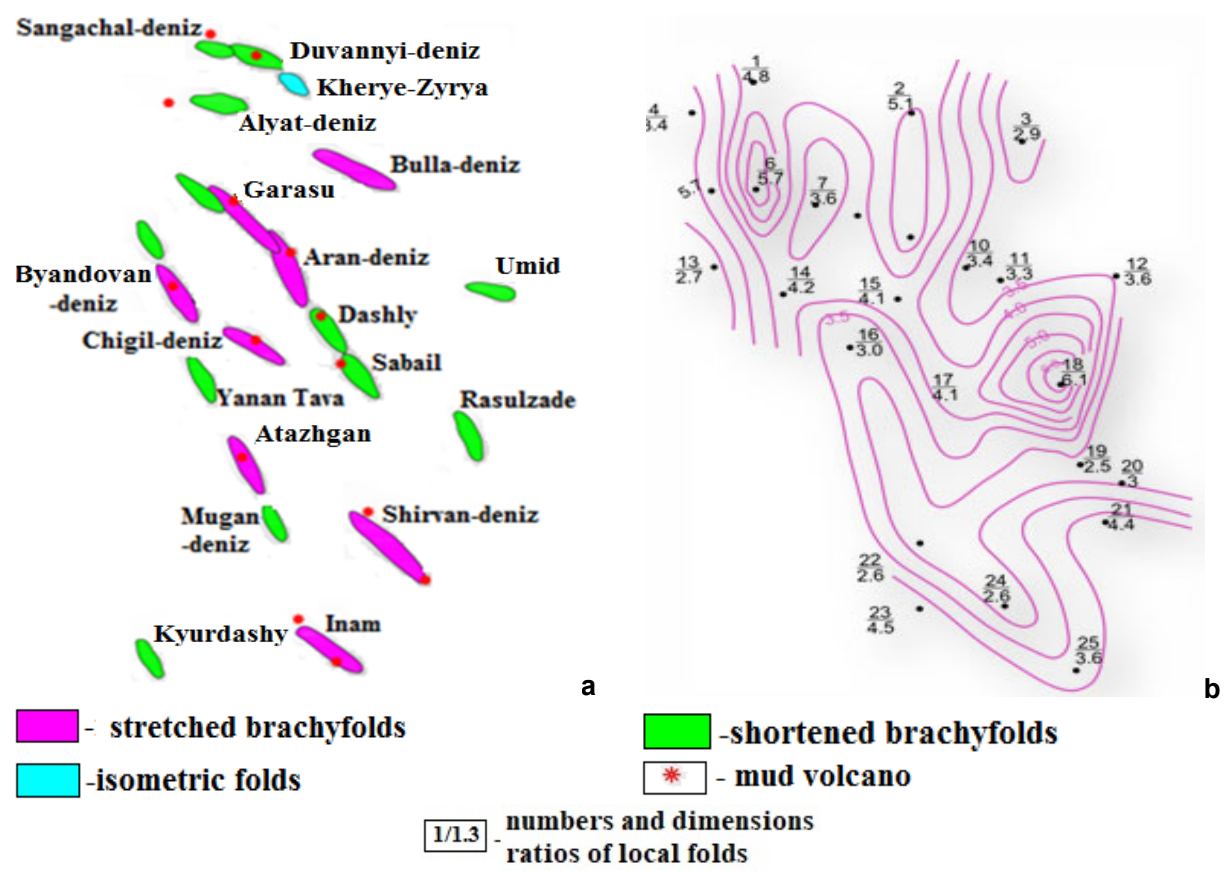

Fig. 5. Scaled morphological depiction of local uplifts of the Baku archipelago (a) and its isomorphic map (b) 


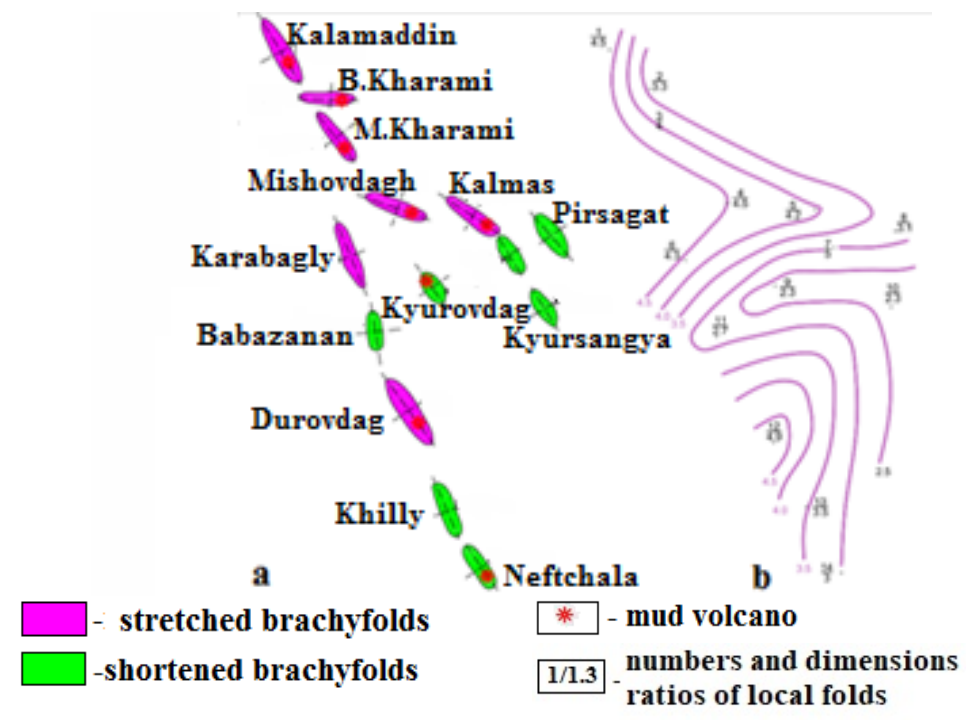

Fig. 6. Scaled morphological depiction of local uplifts of the Lower Kura depression (a) and its isomorphic map (b)

Here 10 out of 15 local uplifts have been complicated by mud volcanoes, moreover, large number of salsas and gryphons have evolved in the studied area. The isomorphic map (Fig. 6) built for the depression shows relatively regularly arranged isolines and their values ranging between $2,3-4,9$, which serves as a sign of relatively evenly distributed compressional stresses all around the area (Fig. 6). Despite all of the mentioned above intensity of compressional stresses grows from the central part of the area towards the north. This is probably caused by contiguity of the northern part of the Lower Kur depression with the AlatLangabiz tectonic zone, which is characterized by intense compressional stresses. Out of 17 local uplifts within this depression 10 are oil-, 2 - gas, 2 - oil and gas bearing, the remaining are considered perspective. Despite compressional stresses in the Lower Kur depression are less intense than those of the Kur-Gabirri area, presence of mud volcanoes in and greater hydrocarbon content of the former, great thickness $(9-20 \mathrm{~km})$ of the sedimentary cover in the depression and pelitic facies (that are the main potential source rock in the regional cross section) wellformed in the sedimentary basin, continuous subsidence of the basin floor in an uncompensated environment caused the abovementioned source rock to be buried at more favorable temperature and pressure environment.

The Godin massif that constitutes the foundation of the Turkmen shelf is a hypsometrically significantly uplifted slab of the crystalline basement and its sedimentary cover is basically represented by the Cenozoic rock complex.
One of the reasons for the Godin massif's uplifting is most probably the geostatic differential pressure generated by the sedimentary mantle upon and around the massif under conditions of compressional stresses within the SCB. High values of the differential between geostatic pressures upon the Godin massif and around it suggest influence of this difference exerted on vertical movements of the massif. The continental denudation environment of the massif lasted, basically, from Paleozoic to Upper Cretaceous. By the end of the Cretaceous its isostatic state levelled with that of the South Caspian basin floor and its evolution went on under the same paleogeographic conditions. The onset of deposition within the massif falls on the Upper Cretaceous. The thickness of the sedimentary cover here reaches $8-10 \mathrm{~km}$ (Oil and gas perspectives..., 2015), whereas moving westwards towards the central part of the SCD it is up to $25 \mathrm{~km}$ and above (Mamedov et al., 1995). Since relatively higher hypsometric level of the crystalline basement within the Godin massif causes compressional stresses generated in the sedimentary mantle of the SCB to be screened from the Turkmen shelf, local uplifts therein have been formed by lateral bending mechanisms, they are underdeveloped, of isometric and short brachiform, have random areal arrangement and there is no regularity observed in their spatial arrangement. This case is clearly manifested by highly sparse isolines and their low values on the isomorphic map created for the area (Fig. 7).

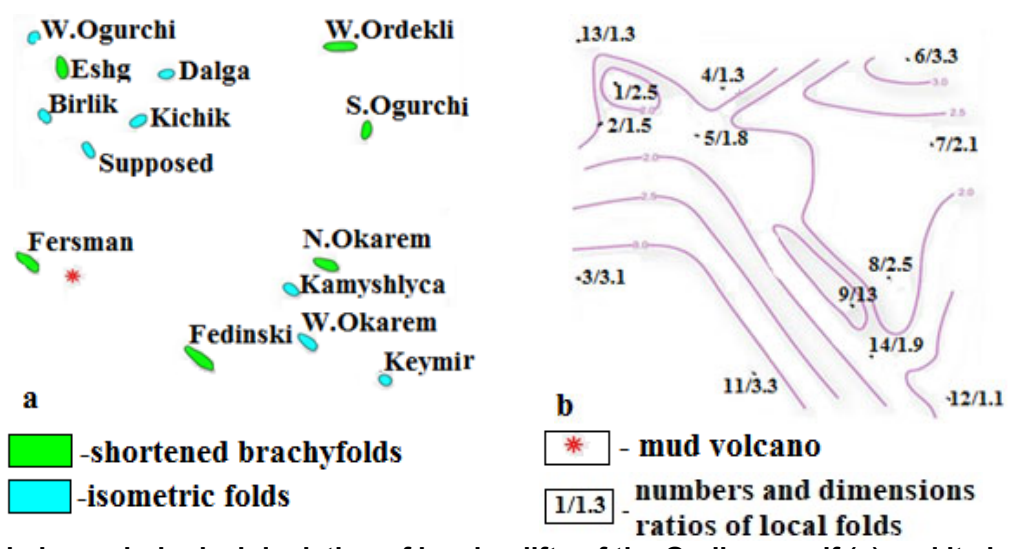

Fig. 7. Scaled morphological depiction of local uplifts of the Godin massif (a) and its isomorphic map (b) 
The map shows the isolines ranging between 1,3-3,3. There is nearly no mud volcanism developed on the Godin massif, but one mud volcano is associated with a deep fault in the southern edge of the massif (Lebedev, 1987). When it comes to oil and gas content of the local uplifts located on the Godin massif part of the Turkmen shelf, no hydrocarbon field has been discovered yet and this is the reason why all of the local uplifts identified on the Godin massif have been assigned to a group with unestablished oil and gas potential (Oil and gas perspectives..., 2015). As described above, relatively small thickness of the sedimentary cover in the area and its formation under unfavorable paleogeographic conditions, underdevelopment of compressional stresses have prevented objective appraisal of the oil and gas content of the area.

Since the occurrence of sedimentation in the environment of compressional stresses within the space surrounding the massif had had a positive effect on its rate, increase of the geostatic pressure caused the graben-shaped basin floor to subside more rapidly (Narimanov, 2005). With the exception of the Godin massif of the Turkmen shelf, these circumstances intensified compressional stresses even more and, thus, plicated dislocation taking place due to the mainly longitudinal bending mechanism in the sedimentary cover.

Continuous evolution and plate convergence of the Greater and Lesser Caucasus collisions causes increasing compressional stresses all along the slopes of the South Caspian megadepression. Subjection of the narrow northwestern part of the Iranian plate to bending deformation enabled formation of the western slope of the South Caspian depression and, in this connection, its geographic isolation from the Kur depression (Narimanov, 2005).

Great thickness (over $14 \mathrm{~km}$ ) of the predominantly shaly Miocene-Quaternary sediments in the South Caspian depression in presence of compressional stresses prepared the ground for the formation of diapir type structures, majority of which have been complicated by mud volcanoes. This is the reason why, excepting the Godin massif, the folding process in the Oligocene-Pliocene sediments takes place due to compression of rheologically active Oligocene-Miocene sediments against cores of the folds developed in the underlying strata. The onset of the evolution of the majority of local uplifts of the Baku and Absheron archipelagos and the pre-Alborz depression no later than by the end of Miocene is known. From this aspect, 2500-3000 $\mathrm{m}$ thick middle and upper Miocene sediments of the Baku Archipelago generated the geostatic pressure necessary to trigger there the lateral bending mechanism. Nonetheless, most of the folds developed in the sedimentary cover of the archipelago are long and short brachyfolds, what is indicative of the longitudinal bending mechanism, even more intense than the lateral bending mechanism, taking part in their formation. This was caused by rheologically relatively active OligoceneQuaternary sediments and intensification of compressional stresses during the same geologic time span. The Baku archipelago being an example, shows the varying rate of folding processes, generally increasing as a function of time. This case can be observed from the changing evolution rate during geologic time span of a series of folds of the Baku archipelago (Narimanov, 2005).

The studied local uplifts of the Baku Archipelago are syndepositional, which is very typical of diapir type structures. Nevertheless, it should be noted, that the rate of the fold development was varying. While the rate of evolution in the Pliocene increased from the north-west to the southeast, in the Quaternary it sharply goes up from the southeast to the north-west. This is associated with distribution properties of compressional stresses within the Baku Archipelago abundant in mud volcanoes and shows their attenuation southwards (Narimanov, 2005).

Variations in the rate of evolution of local uplifts during the geological time span under consideration are typical for the other structural units of the SCMD (Lower Kur depression, Absheron Archipelago etc.) as well.

As a rule, mud volcanoes widespread in the circum-Pacific mobile and Alpine-Himalayan orogenic belts are associated with subduction and collision zones where compressional stresses are extensively developed (Rahmanov, 1995). This shows that mud volcanoes are indicative of compressional stresses, that is to say, they are indices of compressional stresses generated in a thick sedimentary cover containing mainly clay. The environment under compressional stresses that had basically formed from late Miocene had direct impact upon the deposition process. Its rate in the sedimentary basin varies as a function of time and space (Buryakovski et al., 1991).

According to (Buryakovsky et al. 1991) while the deposition rate being $0.4 \mathrm{~mm} / \mathrm{year}$ in the central part of the South Caspian, it is 3-4 mm/year on its shelf and 6 $\mathrm{mm} /$ year at the Kur mouth (Buryakovski, et al 1991). Nevertheless, the thickness of Lower Pliocene sediments only grows up to 6-7 km towards the central part of the South Caspian depression. This is typical of the overlying sediments as well. In this connection, growing thickness of Middle and Upper Miocene sediments is observed along the western slope of the depression (Mamedov et al., 1995). Despite the fact that the thickness of the overlying sediments decreases in that direction and they bend in the form of a regional uplift (Oil and gas perspectives..., 2015) and that the Paleogene-Miocene sediments had been displaced beneath the Lower Pliocene sediments no later than in the Early Pliocene. This is confirmed by decrease in thickness of the Lower Pliocene sediments towards the crestal part of the abovementioned regional uplift, i.e. evolution of this regional uplift, that extends submeridionally, falls upon the period of formation of the Lower Pliocene sediments. These factors indicate active sublatitudinal compressional stresses (generated in the western slope of the SCD) starting in Later Miocene within the limits of the Baku Archipelago and central segment of the South Caspian. Presence of these stresses causes incompact deposit to be accumulated in the central, that is, deeper part of the basin. Periodic transportation of sediments accumulated on the continental slope of the South Caspian basin, which is the relict of the Tethys ocean, by turbidity currents towards the basin center is the special case of the aforementioned process. Thus, despite lower deposition rate in the deeper part of the basin (Buryakovski et al., 1991), in comparison with other segments, the situation mentioned above causes increasing thickness of Miocene - Quaternary sediments towards the deeps. At the same time complex graben-shaped crystalline basement of the basin had increased its rate of subsidence even more and had triggered formation of pre-syndepositional brachiform diapiric structures complicated by mud volcanoes before the inversion processes occurred.

Although the South Caspian depression is surrounded by the active collision zones it is, even at present, evolving as a negative geostructural unit shaped like a closed uncompensated intermountain intracontinental basin characterized by intense subsidence and deposition processes.

As a result of complication by fault and fracture networks the complex graben-shaped crystalline basement of the South Caspian basin has increased the basin's responsiveness to compressional stresses as well as to rising 
geostatic pressure. Geostatic pressure has a positive impact on intensity of compressional stresses with ensuing increasing subsidence rate of the basin floor. Such an environment created favorable conditions for formation of diapir folds and syndepositional folds are characterized by oil and gas opportunities. This comes from formation of clay diapirs being associated with high clay content of the section, and clays, in turn, are the best quality and most widespread source rocks where accumulated organic matter (OM) turns into hydrocarbon at favorable temperature and pressure conditions.

High clay content of the SCD sedimentary cover, and of the Oligocene-Quaternary section in particular, and development of associated clay diapirs and mud volcanoes are grounds for statements on sedimentary formations rich enough with organic matter for the time period mentioned above. In order to figure this out we tried to reveal the connection of the geodynamic environment with change in percentage of organic matter in rock formations that constitute the normal lithostratigraphic section of the area (Yagubov et al., 1971). Build-up of compressional stresses, the rate of burial of deposited sediments, geothermal gradient, tectonic and seismic activity, complication of the basement with faults have a significant impact upon generation of oil and gas in the basin and formation of their accumulations. Meanwhile, generation of oil and gas can be supported by deposition and continuous basin floor subsidence processes only. The average deposition rate in the South Caspian depression from the Later Mesozoic to the Oligocene was $50 \mathrm{~m} / \mathrm{mln}$.y and this process occurred in an oceanic environment void of compressional stresses (Narimanov, 2003). In the Oligocene - Early Miocene this region was characterized by the onset of compressional stresses in the marginal sea setting with the deposition rate of $135 \mathrm{~m} / \mathrm{mln}$.y. This rate ensures accumulation of up to $2 \%$ of OM in potential source rock (Sokolov, 1985). In Pliocene-Quaternary the deposition rate rose to 1400 $1600 \mathrm{~m} / \mathrm{mln} . \mathrm{y}$. , which is a favorable environment for accumulation of up to $10-15 \%$ of OM in potential source rock. Apparently, OM accumulated in sediments composed primarily of clays and the deposition rate in the SCD that is delimited by collision and relict subduction zones in Pliocene-Quaternary are directly proportional to the amount of compressional stresses. Based on the aforesaid, the Upper Cretaceous, Maykopian and Productive Series (PS) potential source rocks of Mesocenozoic sediments are capable of generating commercial volumes of oil and gas. Nevertheless, it should be taken into account that the PS have not completely entered into the oil and gas generation zone in the SCD, that is why hydrocarbons generated by them cannot fully saturate their reservoir rocks (Narimanov, 2003). With this case we have grounds for the statement that PS reservoir rocks have been saturated by hydrocarbons generated not exclusively by the PS sediments, but by the Oligocene-Miocene sedimentsas well or even more. Catagenetic maturation of $\mathrm{OM}$, on the other hand, depends, along with formation temperature, on dynamic processes (Sokolov, 1985) accompanied by mud volcanism that is the reason for generation of additional heat flow, i.e. compressional stresses are one of the motive forces for dynamocatagenesis in oil and gas generation. Apparently, in geodynamically and tectonically active negative geostructural units, that is within intermountain depressions, compressional stresses, mud volcanism and oil and gas content are strongly interrelated and mutually conditioned processes.

As for the Godin massif of the Turkmen shelf, in spite of a relatively higher local temperature gradient, lack of compressional stresses in the sedimentary cover, very low tectonic activity and almost absence of dynamocatagenesis are indices of a low oil and gas generating potential in hypothetic source rocks of the regional cross-section. The paleogeographic setting, on the other hand, gives grounds for the statement that shallow water, its relatively higher mobility and that of the sediments cannot be deemed as a favorable environment for accumulation of enough OM. However, presence of compressional stresses and tectonic processes associated with them within the sedimentary cover surrounding the Turkmen shelf and the Godin massif may cause migration of the part of available fluids towards the Turkmen shelf and the Godin massif.

\section{Conclusions}

1. Since the South Caspian depression is surrounded by collision and relict subduction zones, compressional stresses have evolved to various extents throughout the area within each structural unit and are not evenly distributed.

2. The extent of development of mud volcanism in structural units under investigation is directly proportional to intensity of compressional stresses that can be considered as indicator of evolution of mud volcanoes, absence of mud volcanoes within the Godin massif is associated with unfavorable compressional stresses, lithofacies content of the sedimentary cover and its thickness.

3. Development of compressional stresses within the South Caspian depression and similar geostructural elements have a positive impact upon their oil and gas content, likewise, compressional stresses, mud volcanism and oil and gas content form a single process within negative geostructural elements of regions with geodynamically and tectonically active environment.

4. Compressional stresses of intermountain depressions active from geodynamic and tectonic perspective can be qualitatively assessed by means of isomorphic map built based on morphological properties of local uplifts and their development promotes mud volcanism processes and oil and gas content.

\section{References}

Ahmedov, A.H. (1987). The mechanism of formation of the South Caspian megadepression and main patterns of its tectonic evolution. Oil and gas, 3, 25-30.

Aliyev, A.I., Bagir-zade, F.M., Bunyat-zade, Z.A. et al. (1984). Map of oil and gas fields and perspective structures of the Azerbaijan SSR. Institute of Geology after academician Gubkin I.M. of the AzSSR AS.

Buryakovski, L.D., Jafarov, I.S., Karimov, V.Y. (1991). Prospecting and exploration of marine oil and gas fields. Moscow, Nedra.

Gamkrelidze, I.P. (1982). Mobilism and tectonic issues of the Caucasus. In "Issues of the Caucasus geodynamics". Moscow: Nauka. P. 4-8.

Lebedev, L.I. (1987). The Caspian Sea. Geology and oil and gas content. Moscow: Nauka.

Mamedov, P., Babayev, D. (1995). South Caspian MegatroughSeismostratigraphy. Presented at the AAGP International Conference Exhibition, Nice, France, September 1995, 14.

Narimanov, N.R. (2003). Geodynamic aspects of the formation of the sedimentary cover of the South Caspian depression. Oil and gas geology,6, 26-31.

Narimanov, N.R. (2003). Oil and gas generation potential of the South Caspian depression. AOE (Azerbaijan Oil Economy), 3, 1-7.

Narimanov, N.R. (2005). Geodynamic aspects of the formation of the structures in the South Caspian depression.AOE (Azerbaijan Oil Economy), 9, 14-21.

Narimanov, N.R. (2005). Geodynamic environment of the flanking of the South Caspian megadepression. Azerbaijan geologist, 10, 26-32.

Oil and gas perspectives of the Turkmenistan shelf of the South Caspian megadepression (8 November 2015). Retrieved from http://www.oilgas.gov.tm/compositions/19.

Rahmanov, R.R. (1995). World mud volcanism. Theses of the reports of the III International Conference of the Azerbaijan Petroleum Geologists society, Baku.

Sokolov, B.A. (1985). Evolutional and dynamic criteria of evaluation of the oil and gas content of the Earth interior. Moscow: Nedra.

Yagubov, A.A., Alizade, A.A., Zeynalov, M.M. (1971). Mud volcanoes of the Azerbaijan SSR. Atlas. Baku.

Zonenshayn, L.P., Kuzmin, M.I., Natapov, L.M. (1990). Tectonics od the lithospheric plates of the USSR. V. 2. Moscow: Nedra. P. 220-223.

Надійшла до редколегії 30.04.21 
В. Гурбанов,

E-mail: vaqifqurbanov@mail.ru;

Н. Наріманов,

E-mail: nariman.narimanov40@asoiu.edu.az;

Г. Насібова,

E-mail: gultar_nasibova_1@yahoo.com

Азербайджанський державний університет нафти і промисловості,

пр. Азадлиг, 34, м. Баку, AZE1010, Азербайджан

\section{ВПЛИВ СТИСКАЛЬНИХ НАПРУГ У ПІВДЕННО-КАСПІЙСЬКІЙ МЕГАЗАПАДИНІ НА РОЗВИТОК І НАФТОГАЗОНОСНІСТЬ ЛОКАЛЬНИХ ПІДНЯТТІВ}

У Південнокаспійській мегазападині (ПКМЗ) розелянуто такі структурні елементи: межиріччя Кури і Габирри, Абшеронський і Бакинський архіпелаги, Нижньокуринська западина і масив Годіна, що відрізняються геодинамічним і структурно-тектонічним розвитком, а також нафтогазоносністю.

Для вирішення поставленого завдання було проаналізовано геодинамічний режим Пкмз, на основі складених автором геодинамічної схеми Центрального сегмента Середземноморського гірничо-складчастого пояса, схеми оріснтації стискальних напруг в НКВЗ і вперше розробленої методики їхньої якісної оцінки в межах структурних елементів шляхом складання карт ізоморф. Останні дозволяють визначити інтенсивність і характер поширення стискальних напруг, особливості їхнього впливу на складкоутворення, нафтогазогенерацію і формування скупчень вуглеводнів.

Межиріччя Кури і Габирри розміщено на заході ПКЗ між близько розташованими Мало- і Великокавказською колізіями. Воно характеризується нафртогазоносними і перспективними субииротно орієнтованими лінійними складками, ускладненими діз'юнктивами і грязевулканізмом. Значення ізоліній карти ізоморф та їхня щільність свідчать про велику інтенсивність стискальних напруг північно-західної орієнтації.

Абшеронський архіпелаг $є$ західним елементом Абшероно-Прибалханської залишкової субдукції. Зәідно з картою ізоморф з густою мережею ізоліній субширотної орієнтації архіпелаг ускладнений лінійною складчастістю, а також насувами, поперечними зрушеннями, грязевулканізмом, нафтоогазоносністю і нафтогазопроявами, що свідчать про розвиток тут інтенсивних стискальних напруг.

У Бакинському архіпелазі й Нижньокуринській западині (НКЗ) розвиток складок відбувався за напружень поздовжнього і поперечного вигинів. На картах ізоморф слабковиражена лінійність стискальних напруг очевидно пов'язана 3 формуванням між ними Західного борту ПКЗ у вигляді регіонального субмеридіонального підняття. Воно розвивалося під впливом стискальних напруг, що виникають під впливом північно-східного виступу Аравійської плити на Ірано-Афганську. НКЗ є сухопутним продовженням Бакинського архіпелагу. ї̈ антиклінальні зони, регіональні розриви, грязевулканізм і нафтогазоносність мають продовження в останньому.

Масив Годіна найсхідніший структурний елемент із розглянутих зі слабковідбитою складчатістю невстановленої перспективності. Ізолінії карти ізоморф не мають безпосереднього зв'язку з локальними підняттями, що свідчить про відсутність тут чітко виражених стискальних напруг.

Проведений аналіз дозволив визначити ступінь розвитку стискальних напруг, їхній вплив на формування осадового розрізу, складкоутворення, грязевулканізм і нафтогазоносність розелянутих структурних елементів.

Ключові слова: грязевулканізм, стискальні напруги, карти ізоморф, Абшеронський архіпелаг, нафта, газ.

\section{В. Гурбанов}

E-mail: vaqifqurbanov@mail.ru;

Н. Нариманов,

E-mail: nariman.narimanov40@asoiu.edu.az;

Г. Насибова

E-mail: gultar_nasibova_1@yahoo.com

Азербайджанский государственный университет нефти и промышленности,

пр. Азадлыг, 34, г. Баку, AZE1010, Азербайджан

\section{ВЛИЯНИЕ СЖИМАЮЩИХ НАПРЯЖЕНИЙ В ЮЖНОКАСПИЙСКОЙ МЕГАВПАДИНЕ НА РАЗВИТИЕ И НЕФТЕГАЗОНОСНОСТЬ ЛОКАЛЬНЫХ ПОДНЯТИЙ}

В Южнокаспийской мегавпадине (ЮКМВ) рассмотрены следующие структурные элементы: междуречье Куры и Габырры, Абшеронский и Бакинский архипелаги, Нижнекуринская впадина и массив Година, отличающиеся геодинамическим и структурно-тектоническим развитием, а также нефтегазоносностью.

Для решения поставленной задачи был проанализирован геодинамический режим ЮкМВ на основе составленных автором геодинамической схемы Центрального сегмента Средиземноморского горно-складчатого пояса, схемы ориентации сжимающих напряжений в ЮКВ и впервые разработанной методики их качественной оценки в пределах структурных элементов путем составления карт изоморф. Последние позволяют определить интенсивность и характер распространения сжимающих напряжений, особенности их влияния на складкообразование, нефтегазогенерацию и формирование скоплений углеводородов.

Междуречье Куры и Габырры находится на западе ЮКМВ между близко расположенными Мало- и Большекавказской коллизиями. Оно характеризуется нефтегазоносными и перспективными субширотно ориентированными линейными складками, осложненными дизъюнктивами и грязевулканизмом. Значения изолиний карты изоморф и их плотность свидетельствуют о большой интенсивности сжимающих напряжений северо-западной ориентации.

Абшеронский архипелаг является западным элементом Абшероно-Прибалханской остаточной субдукции. Согласно карте изоморф с густой сетью изолиний субииротной ориентации архипелаг осложнен линейной складчатостью, а также надвигами, поперечными сдвигами, грязевулканизмом, нефтегазоносностью и нефтегазопроявлениями, свидетельствующими о развитии здесь интенсивных сжимающих напряжений.

На Бакинском архипелаге и Нижнекуринской впадине (НКВ) развитие складок происходило при напряжениях продольного и поперечного изгибов. На картах изоморф слабовыраженная линейность сжимающих напряжений очевидно связана с формированием между ними Западного борта ЮКВ в виде регионального субмеридионального поднятия. Оно развивалось под влиянием сжимающих напряжений, возникающих под воздействием северо-восточного выступа Аравийской плиты на Ирано-Афганскую. НкВ является сухопутным продолжением Бакинского архипелага. Ее антиклинальные зоны, региональные разрывы, грязевулканизм и нефтегазоносность имеют продолжение в последнем.

Массив Година самый восточный структурный элемент из рассмотренных со слабовыраженной отраженной складчатостью неустановленной перспективности. Изолинии карты изоморф не имеют непосредственной связи с локальными поднятиями, что свидетельствует об отсутствии здесь четко выраженных сжимающих напряжений.

Проведенный анализ позволил определить степень развития сжимающих напряжений, их влияние на формирование осадочного разреза, складкообразование, грязевулканизм и нефтегазоносность рассмотренных структурных элементов.

Ключевые слова: грязевулканизм, сжимающие напряжения, карты изоморф, Абшеронский архипелаг, нефть, газ. 